\title{
Factor V Measurement
}

National Cancer Institute

\section{Source}

National Cancer Institute. Factor V Measurement. NCI Thesaurus. Code C98726.

The determination of the amount of factor $\mathrm{V}$ present in a sample. 